\title{
子どものからだの異変とその対策
}

前橋明

\section{How to find and manage physical abnormalities of young children}

\author{
Akira Maehashi
}

\begin{abstract}
The relationship of body temperature to movement and daily life in a nursery was examined in 181 children at a day care center, and the importance of body temperature to the life and health management of the children was evaluated. (1) The children were divided into three groups. Group A comprised 28 children (15.5\%) whose body temperature exceeded 37.0 degrees at 9:00 a.m., and whose average temperature was 37.19 degrees. Group B comprised 127 children (70.1\%) whose body temperature ranged from 36.0 to 37.0 degrees, and whose average temperature was 36.48 degrees. Group C comprised 26 children (14.4\%) whose body temperature was under 36.0 degrees, and whose average temperature was 35.58 degrees. (2) Children in Groups B and C, whose temperature was under 37.0 degrees when they arrived at the day care center, showed a temperature rise after movement and play in the morning. On the other hand, the children in Group A, whose temperature exceeded 37.0 degrees, showed a decrease in temperature in spite of walking an average of 3209 steps per person in the morning, which was about 200-400 steps more than Groups B or C. (3) Keeping early hours, having regular bowel movements after breakfast, and walking to school help to raise children's body temperature when they reach school. This temperature increase assists mental and physical warming up, encourages efficient exercise, and aids better release of energy. If more steps are taken to improve the quality of exercise after 3:00 p.m. as well as in the morning, problems such as children needing snacks before supper or going to bed late will be solved. The children will become hungry after playing and will be ready to eat supper at the right time. At night they will feel moderately tired and become sleepy around 8:00 p.m.. Recently there has been a rapid increase in the number of children who tend to watch TV or play video games while eating snacks before their parents come home, and this is exactly what needs to be addressed in order to improve juvenile health in modern life. In conclusion, physical exercise and play are considered important in children for activating the autonomic nervous system, which controls body temperature.
\end{abstract}

\section{Key words : children's body temperature, physical exercise, day care center, nursery life, health management}

(Japan J. Phys. Educ. Hlth. Sport Sci. 49: 197-208, May, 2004)

早稲田大学人間科学部健康福祉科学科

于 359-1192 埼玉県所沢市三ヶ島 2-579-15

連絡先 前橋 明
Waseda University,School of Human Sciences, Department of Health Science and Social Welfare 2-579-15 Mikajima, Tokorozawa, Saitama 359-1192 Correspondingauthor maehashi@waseda.jp 
キーワード：子どもの体温, 運動, 保育園, 園内 生活, 健康管理

\section{Iはじめに}

10 年ほど前から，保育の現場で，朝からねむ けやだるさを訴えて，ぐずぐず文句の多い子が目 立ち始めた。保育園览や幼稚園児を対象に, 疲労 症状を調査したところ，睡眠時間が 9 時間程度と いう子どもに疲労の訴えが多く（前橋ほか， 1993b，1994），しかも，「物事に熱心になれない」 「きちんとしていられない」などの精神疲労時の 症状の訴え（前橋ほか，1997）が増えていること がわかった，疲れはあっても，睡眠ですっきり回 復し, 翌日に持ち越さないのが子ども本来の姿で あったのに，夜型生活で，生活のリズムが乱れ， 疲れが蓄積していた. 午後 9 時前就寝, 午前 7 時 前起床，朝食を食べ，排便を済ませて登園すると いう望ましい生活習慣を持つ園児は非常に少なく なったのが，この平成時代の特徵であろう。

特に近年は，保育園や幼稚園への登園後，無気 力で遊ばずにじっとしていたり，何をしても続か ず，集中力や意欲のない子，さらには，落ち着き がなく，いらいらし，すぐにカーッとなる子，疲 れている子（石井ほか，1993，1996；前橋ほか, 1993a；毎日新聞，2000a ; 山陽新聞， 2001 ; 渋 谷ほか，1996）が目につくようになった。おかし さを感じ，保育園に登園してきた幼児の朝の体温 を計ってみると, 午前 9 時に $36{ }^{\circ} \mathrm{C}$ 未満の子ども たち（低体温の子）だけでなく，37.0 ${ }^{\circ} \mathrm{C}$ を越え $37.5{ }^{\circ} \mathrm{C}$ 近い子どもたち（高体温の子）が増えてい たのである．実際には，朝に $36^{\circ} \mathrm{C}$ 未満の低体温 の子どもと $37^{\circ} \mathrm{C}$ 以上の高体温の子どもが増えて， これらを合わせると，約 3 割になる（毎日新聞, 2000b）ことを確認した.

子どもたちの生活実態を調べてみると，「運動 しない」，「睡眠時間が少ない」，「朝食をしっかり 摂っていない」，「温度調節のなされた室内でのテ レビ・ビデオ視聴やゲームあそびが多い」という 生活習慣の乱れと睡眠リズムのズレ，身体にとっ ての活動内容の悪さが共通点として確認された。
また，近年の子どもたちは，疲れを次の日に持ち 越しており,その疲れも身体的疲れだけではなく， 精神的な疲れをも訴え, 持続させている（前橋ほ か, 1997)。 そして, 午前中に体温が $1{ }^{\circ} \mathrm{C}$ 以上変 動する子どもが増加している（毎日新聞，2001）. そういったところに，非常に危機感を感じるとと もに，体温調節がうまくできないのは，基本的に は自律神経の働きがうまく機能していないからと 考え，生活リズムの改善と運動の積極的な実践を 行うこととした。

その結果, 子どもたちの体温調節機能に良き方 向への変化を見い出したので，本稿では，近年の 幼児のからだの問題，中でも体温調節に問題をも つ子どもたちに対する「運動・あそび」を中核に した対策と保育実践の実際を報告し，この 21 世 紀の子育てや保育，健康福祉科学ならびに体育学 に寄与すべき知見を検討・整理し，提言を試みる こととした.

\section{II 幼児の体温実態}

岡山県内の保育園の 4 歳児 160 名（男児 67 名, 女児 93 名）を対象に，就寝時刻と睡眠時間を調 查し, 体温と両手握力值の園内生活時の実態を 1 年間測定した，体温の測定は，テルモ製の電子体 温計を用い，体温測定に習熟した保育者が幼児の 腋窩温（岡崎，1998）を測定した。まず，乾いた タオルで幼児の腋窩の汗を軽く拭き，腋窝の奥に 体の前下方から上方 45 度の角度で体温計を挿入 し，電子音が鳴り終わって測定值を読み，記録し た，測定は，登園時 (午前 9 時)，昼食前（午前 11 時 30 分)，降園前（午後 4 時）に実施した。

そして, 各測定時における各月の体温の平均值, ならびに午前 9 時における $36.0{ }^{\circ} \mathrm{C}$ 未満（低体温） 児と $37^{\circ} \mathrm{C}$ 以上（高体温）児の出現頻度を確認し た。また，握力測定は，ヤガミ製握力計を両手で 握らせ，体温測定時に並行して測定した。ささらに， 幼児の就寝時刻と睡眠時間，体温，握力，午前 9 時の高体温児出現率，午前 9 時の低体温児出現率 相互の相関係数を求め，子どもたちの身体状況相 互の関連性を確認した。 


\section{1. 体温の年間変動}

午前 9 時における 4 歳児の月別平均体温を男女 別に比較すると，6月では，男児 $36.82^{\circ} \mathrm{C}$ ，女览 $36.86{ }^{\circ} \mathrm{C}$ となった（図 1).7月では，男児 $36.81^{\circ} \mathrm{C}$, 女児 $36.87^{\circ} \mathrm{C}$ となり，1 年の中で高值となった. その後，8月から 12 月にかけて低下した．結果的 には，体温は，11月・12月が最低值となり，そ の後，高まる傾向にあり，3月では，男児 $36.73{ }^{\circ} \mathrm{C}$ ，女児 $36.72{ }^{\circ} \mathrm{C}$ となった。して，午前 9 時から午前 11 時 30 分にかけての体温の変動は, 通常, 男女ともに上昇することを確認した（表 1$)$.
この体温の年間変動は，男女ともほぼ一致して おり，類似した様相を呈した。すなわち，体温の 変動は, 夏季から冬季にかけて低下し，その後, 高まるというパターンがみられ，男児 $(\mathrm{t}=5.33$, $\mathrm{p}<0.001)$ ，女児（ $\mathrm{t}=3.03 ， \mathrm{p}<0.01 ）$ ともに，6 月の体温に対して，12月の体温は有意に低下し た。

また，体温が $37.0{ }^{\circ} \mathrm{C}$ 以上， $36.0^{\circ} \mathrm{C}$ 末満の幼児の 発現頻度は，表 2 に示す通りであり，季節的な影 響を受けることが示された。とくに $36.0^{\circ} \mathrm{C}$ 未満児 の発現頻度は, 日長時間との相関性が高く, 10

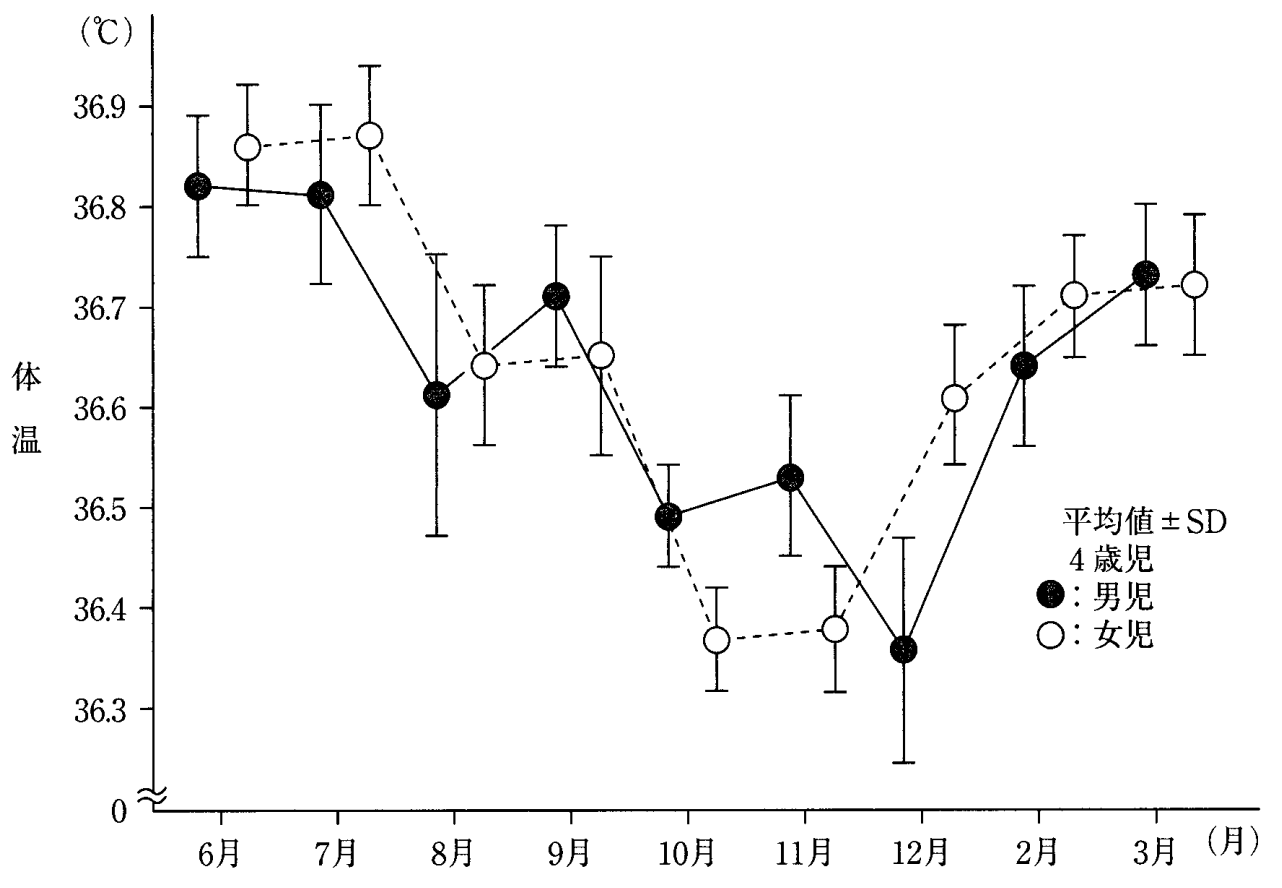

図 1 幼児の午前 9 時体温の年間変動

表 1 幼児の園内生活時の体温の年間変動

\begin{tabular}{|c|c|c|c|c|c|c|c|c|c|c|}
\hline \multicolumn{2}{|c|}{ 項目 } & 6 月 & 7月 & 8 月 & 9 月 & 10 月 & 11 月 & 12 月 & 2 月 & 3 月 \\
\hline \multirow[t]{3}{*}{ 男児 } & $9: 00$ & $\begin{array}{r}36.82 \\
\pm 0.33\end{array}$ & $\begin{array}{r}36.81 \\
\pm 0.41\end{array}$ & $\begin{array}{r}36.61 \\
\pm 0.41\end{array}$ & $\begin{array}{r}36.71 \\
\pm 0.33\end{array}$ & $\begin{array}{r}36.49 \\
\pm 0.38\end{array}$ & $\begin{array}{r}36.53 \\
\pm 0.48\end{array}$ & $\begin{array}{r}36.36 \\
\pm 0.46\end{array}$ & $\begin{array}{r}36.64 \\
\pm 0.53\end{array}$ & $\begin{array}{r}36.73 \\
\pm 0.37\end{array}$ \\
\hline & $11: 30$ & $\begin{array}{r}36.88 \\
\pm 0.40\end{array}$ & $\begin{array}{r}36.92 \\
\pm 0.29\end{array}$ & $\begin{array}{r}36.72 \\
\pm 0.45\end{array}$ & $\begin{array}{r}36.85 \\
\pm 0.50\end{array}$ & $\begin{array}{r}36.71 \\
\pm 0.43\end{array}$ & $\begin{array}{r}36.59 \\
\pm 0.52\end{array}$ & $\begin{array}{r}36.78 \\
\pm 0.43\end{array}$ & $\begin{array}{r}36.71 \\
\pm 0.43\end{array}$ & $\begin{array}{r}36.79 \\
\pm 0.43\end{array}$ \\
\hline & $16: 00$ & $\begin{array}{r}36.88 \\
\pm 0.34\end{array}$ & $\begin{array}{r}36.98 \\
\pm 0.33\end{array}$ & $\begin{array}{r}36.94 \\
\pm 0.29\end{array}$ & $\begin{array}{r}36.94 \\
\pm 0.46\end{array}$ & $\begin{array}{r}36.77 \\
\pm 0.39\end{array}$ & $\begin{array}{r}36.81 \\
\pm 0.46\end{array}$ & $\begin{array}{r}36.72 \\
\pm 0.58\end{array}$ & $\begin{array}{r}36.89 \\
\pm 0.32\end{array}$ & $\begin{array}{r}36.81 \\
\pm 0.31\end{array}$ \\
\hline \multirow[t]{3}{*}{ 女児 } & $9: 00$ & $\begin{array}{r}36.86 \\
\pm 0.36\end{array}$ & $\begin{array}{r}36.87 \\
\pm 0.31\end{array}$ & $\begin{array}{r}36.64 \\
\pm 0.25\end{array}$ & $\begin{array}{r}36.65 \\
\pm 0.46\end{array}$ & $\begin{array}{r}36.37 \\
\pm 0.48\end{array}$ & $\begin{array}{r}36.38 \\
\pm 0.52\end{array}$ & $\begin{array}{r}36.61 \\
\pm 0.48\end{array}$ & $\begin{array}{r}36.71 \\
\pm 0.42\end{array}$ & $\begin{array}{r}36.72 \\
\pm 0.42\end{array}$ \\
\hline & $11: 30$ & $\begin{array}{r}36.96 \\
\pm 0.29\end{array}$ & $\begin{array}{r}36.90 \\
\pm 0.33\end{array}$ & $\begin{array}{r}36.86 \\
\pm 0.37\end{array}$ & $\begin{array}{r}36.80 \\
\pm 0.36\end{array}$ & $\begin{array}{r}36.50 \\
\pm 0.54\end{array}$ & $\begin{array}{r}36.67 \\
\pm 0.51\end{array}$ & $\begin{array}{r}36.93 \\
\pm 0.51\end{array}$ & $\begin{array}{r}36.85 \\
\pm 0.44\end{array}$ & $\begin{array}{r}36.77 \\
\pm 0.49\end{array}$ \\
\hline & $16: 00$ & $\begin{array}{r}36.91 \\
\pm 0.25\end{array}$ & $\begin{array}{r}36.94 \\
\pm 0.31\end{array}$ & $\begin{array}{r}36.96 \\
\pm 0.35\end{array}$ & $\begin{array}{r}36.94 \\
\pm 0.38\end{array}$ & $\begin{array}{r}36.63 \\
\pm 0.34\end{array}$ & $\begin{array}{r}36.68 \\
\pm 0.47\end{array}$ & $\begin{array}{r}36.76 \\
\pm 0.54\end{array}$ & $\begin{array}{r}36.82 \\
\pm 0.46\end{array}$ & $\begin{array}{r}36.54 \\
\pm 0.51\end{array}$ \\
\hline
\end{tabular}

分散分析：時刻の要因 $(\mathrm{p}<0.01)$, 月別要因 $(\mathrm{p}<0.01)$ (平均値 $\pm \mathrm{SD})$ 
表 2 登園時における幼児の体温の月別分布（\%)

\begin{tabular}{rcccccc}
\hline \multirow{2}{*}{ 月 } & \multicolumn{3}{c}{ 男 览 } & \multicolumn{3}{c}{ 女 览 } \\
\cline { 2 - 7 } & $37^{\circ} \mathrm{C}$ 以上 & $36^{\circ} \mathrm{C}$ 台 & $36^{\circ} \mathrm{C}$ 未満 & $37^{\circ} \mathrm{C}$ 以上 & $36{ }^{\circ} \mathrm{C}$ 台 & $36^{\circ} \mathrm{C}$ 未満 \\
\hline 6月 & 24.0 & 76.0 & 0 & 44.1 & 55.9 & 0 \\
7 月 & 40.0 & 60.0 & 0 & 42.9 & 57.1 & 0 \\
8 月 & 11.1 & 77.8 & 11.1 & 10.0 & 90.0 & 0 \\
9 月 & 26.1 & 73.9 & 0 & 18.2 & 81.8 & 0 \\
10 月 & 12.0 & 80.0 & 8.1 & 10.5 & 72.1 & 17.4 \\
11 月 & 17.9 & 69.3 & 12.8 & 16.4 & 61.2 & 22.4 \\
12 月 & 11.1 & 66.7 & 22.2 & 25.8 & 61.3 & 12.9 \\
2 月 & 20.0 & 72.5 & 7.5 & 33.3 & 66.7 & 0 \\
3月 & 25.8 & 71.0 & 3.2 & 26.3 & 68.4 & 5.3 \\
\hline
\end{tabular}

月ー12月にかけて多くなった（表 3 ）.月別の日 長時間拈よび，月別平均気温と，高体温・低体温 児の出現率の相関を求めてみると，男児では，低 体温児の出現率と日長時間との関係は, $\mathrm{r}=$ -0.715，女児では， $\mathrm{r}=-0.658$ となり，低体温 児の発現は，日長時間に関わっていることが示さ れた。 また，日長時間と月平均気温と高体温児 · 低体温児の出現率は，男児の低体温に有意な負の 相関（ $\mathrm{r}=-0.690 ）$ が認められた。

\section{2. 幼児の生活習慣・体力・筋力相互の関連性}

保育園児の就寝時刻と睡眠時間, 体温, 握力, 午前 9 時の高体温児出現率，午前 9 時の低体温児 出現率相互の相関係数を求め，男女ともに有意な 相関がみられたものを表 4 にまとめた。つまり， 「1）就寝時刻が遅いと，睡眠時間は短くなり，登 園時の体温は高い。そして，登園時の高体温児も 多い」，「2）睡眠時間が短いと，登園時の体温は 高く，高体温児の出現率も高い」という結果にな り，これまでの「就寝時刻が遅いと睡眠時間は短 く，登園時の体温は低く，疲労感の訴えが多い (甲賀, 1988 ; 前橋, 2000)」といわれているこ ととは逆の様相を呈した。この点を詳細に検討す るため，日長時間の最も長い 6 月をとりあげ，男 児 31 名と女児 33 名の生活状況ならびに身体状沉 を調べ，表 $5 に$ 示した。

つまり, $37^{\circ} \mathrm{C}$ 以上の高体温児の生活状況は, 男児を例に挙げると， $36{ }^{\circ} \mathrm{C}$ 台の子どもに比して 悪いことを確認した。その子どもたちの特徴は,
表 $336^{\circ} \mathrm{C}$ 未満の低体温出現率と日長時間 a)

\begin{tabular}{rrrr}
\hline 月 & 日長時間 & $\begin{array}{c}\text { 男监 } \\
(67 \text { 名 })\end{array}$ & $\begin{array}{c}\text { 女览 } \\
(93 \text { 名 })\end{array}$ \\
\hline 6 月 & 14 時間 27 分 & $0 \%$ & $0 \%$ \\
7 月 & 14 時間 18 分 & $0 \%$ & $0 \%$ \\
8 月 & 13 時間 29 分 & $11.1 \%$ & $0 \%$ \\
9 月 & 12 時間 27 分 & $0 \%$ & $0 \%$ \\
10 月 & 11 時間 23 分 & $8.0 \%$ & $17.4 \%$ \\
11 月 & 10 時間 23 分 & $12.8 \%$ & $22.4 \%$ \\
12 月 & 9 時間 52 分 & $22.2 \%$ & $12.9 \%$ \\
2 月 & 10 時間 55 分 & $7.5 \%$ & $0 \%$ \\
3 月 & 11 時間 55 分 & $3.2 \%$ & $5.3 \%$ \\
\hline 日長時間との相関 $(\mathrm{r})$ & -0.715 & -0.658 \\
\hline
\end{tabular}

a) 岡山県の気象歴

「睡眠時間が 9 時間と短いこと」，「排便の実施率 は $27 \%$ と極めて少ないこと．朝，排便をせずし て登園している子どもが73\%もいること」，「1日 の歩数が平均 3651 歩と誠に少ないこと」であっ た。

\section{III 体温調節に問題をもつ子どもたち への「運動・あそび」を中核に した対策の実際}

\section{1. 実践 1：「朝の運動実践」}

1 年間の体温実態調査の終了後, 調査対象を 181 名に増やし，体温と運動との関連性をみるた めに, $36.0^{\circ} \mathrm{C}$ 末満児と $37.0^{\circ} \mathrm{C}$ 以上児の出現頻度の 多かった 12 月に運動を実践させ，5歳児の体温を 測定した。体温の測定時刻は, 登園した午前 9 時, 
表 4 男女ともに有意な相関のみられた生活ならびに身体状況

(表中の数值は相関係数 $\mathrm{p}<0.05$ の値)

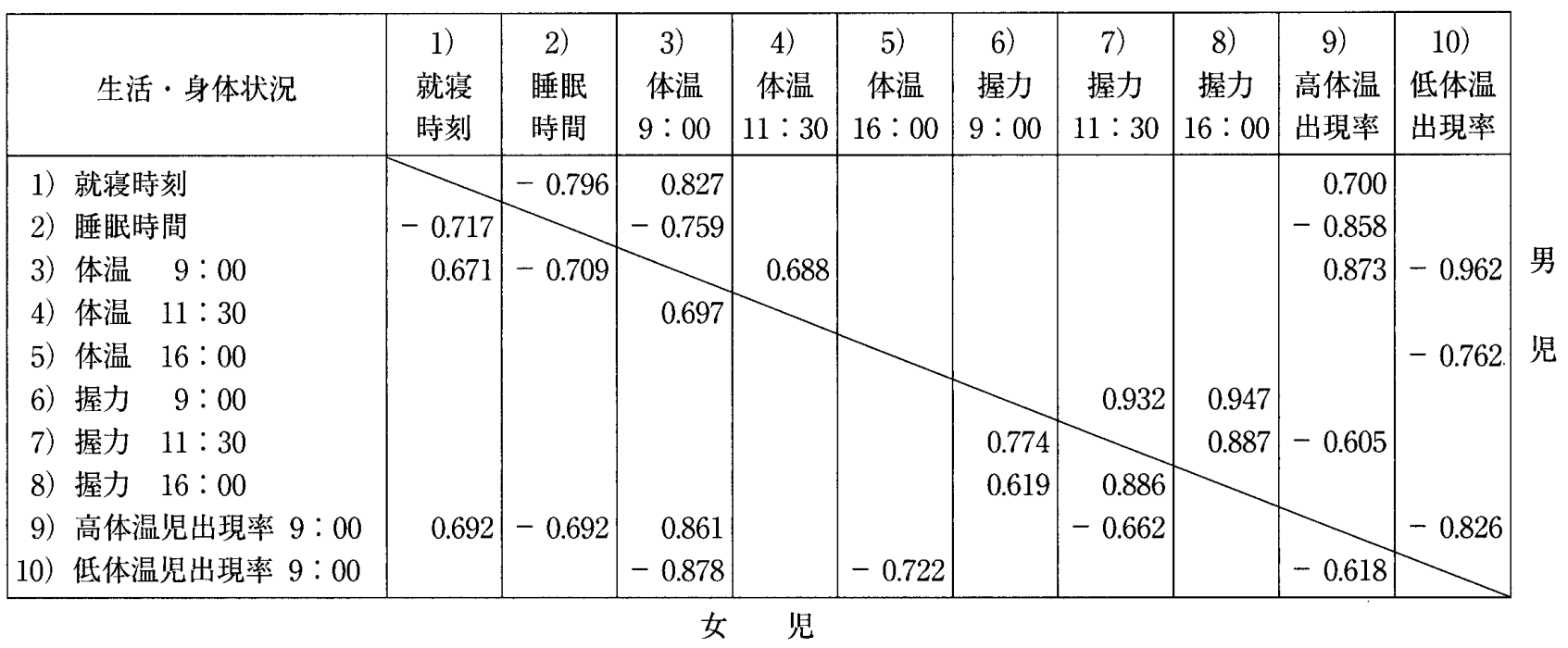

表 56 月に扔ける体温区分別生活・身体状況

\begin{tabular}{|c|c|c|c|c|}
\hline 体温区分 & 性 & $37.0^{\circ} \mathrm{C}$ 以上 & $36.0^{\circ} \mathrm{C}$ 以上 $37.0^{\circ} \mathrm{C}$ 未満 & $36.0^{\circ} \mathrm{C}$ 未満 \\
\hline 人 数 & $\begin{array}{l}\text { 男 } \\
\text { 女 }\end{array}$ & $\begin{array}{l}11 \\
13\end{array}$ & $\begin{array}{l}20 \\
20\end{array}$ & $\begin{array}{l}0 \\
0\end{array}$ \\
\hline 人数比 & $\begin{array}{l}\text { 男 } \\
\text { 女 }\end{array}$ & $\begin{array}{l}35.5 \% \\
39.4 \% \\
\end{array}$ & $\begin{array}{l}64.5 \% \\
60.6 \% \\
\end{array}$ & $\begin{array}{l}0 \% \\
0 \% \\
\end{array}$ \\
\hline $\begin{array}{l}\text { 登園時の平均体温 } \\
(9 \text { 時 })\end{array}$ & $\begin{array}{l}\text { 男 } \\
\text { 女 }\end{array}$ & $\begin{array}{l}37.25 \pm 0.20^{\circ} \mathrm{C} \\
37.18 \pm 0.21^{\circ} \mathrm{C}\end{array}$ & $\begin{array}{l}36.61 \pm 0.25^{\circ} \mathrm{C} * * * \\
36.63 \pm 0.23^{\circ} \mathrm{C} * * *\end{array}$ & \\
\hline 睡眠時間 & $\begin{array}{l}\text { 男 } \\
\text { 女 }\end{array}$ & $\begin{array}{l}9.07 \pm 0.88 \\
9.27 \pm 0.55\end{array}$ & $\begin{array}{l}9.23 \pm 0.54 \\
9.11 \pm 2.08\end{array}$ & \\
\hline 排便実施率 & $\begin{array}{l}\text { 男 } \\
\text { 女 }\end{array}$ & $\begin{array}{l}27.0 \% \\
38.5 \%\end{array}$ & $\begin{array}{l}60.0 \% \\
50.0 \%\end{array}$ & \\
\hline $\begin{array}{l}\text { 登園時 } \\
\text { (9 時) }\end{array}$ & $\begin{array}{l}\text { 男 } \\
\text { 女 }\end{array}$ & $\begin{array}{l}12.45 \pm 1.60 \mathrm{~kg} \\
10.92 \pm 2.55 \mathrm{~kg}\end{array}$ & $\begin{array}{l}13.52 \pm 1.67 \mathrm{~kg} \\
11.35 \pm 2.30 \mathrm{~kg}\end{array}$ & \\
\hline 11 時 30 分 握力 & $\begin{array}{l}\text { 男 } \\
\text { 女 }\end{array}$ & $\begin{array}{l}12.72 \pm 2.23 \mathrm{~kg} \\
11.04 \pm 1.73 \mathrm{~kg}\end{array}$ & $\begin{array}{l}13.67 \pm 1.67 \mathrm{~kg} \\
12.53 \pm 2.49 \mathrm{~kg}\end{array}$ & \\
\hline 16 時 & $\begin{array}{l}\text { 男 } \\
\text { 女 }\end{array}$ & $\begin{array}{l}11.63 \pm 1.83 \mathrm{~kg} \\
11.15 \pm 1.88 \mathrm{~kg}\end{array}$ & $\begin{array}{l}13.22 \pm 1.28 \mathrm{~kg} * * \\
12.50 \pm 2.19 \mathrm{~kg}\end{array}$ & \\
\hline 11 時 30 分 歩数 & $\begin{array}{l}\text { 男 } \\
\text { 女 }\end{array}$ & $\begin{array}{l}2234 \pm 1584 \\
2350 \pm 1655 \\
\end{array}$ & $\begin{array}{l}2847 \pm 1709 \\
2551 \pm 1150\end{array}$ & \\
\hline 16 時 & $\begin{array}{l}\text { 男 } \\
\text { 女 }\end{array}$ & $\begin{array}{l}3651 \pm 1639 \\
3455 \pm 1855\end{array}$ & $\begin{array}{l}4471 \pm 1851 \\
3793 \pm 1067\end{array}$ & \\
\hline
\end{tabular}

体温区分別の差の検定 ${ }^{* *} \mathrm{p}<0.01, \quad{ }^{* * *} \mathrm{p}<0.001$

午前中のボールあそびや鬼ごっこ等の運動あそび の実践を終えた午前 11 時 30 分，部屋の中での諸 活動を済ませた午後 3 時の 3 回とし，電子体温計 を用いて測定した。この体温測定と並行して，幼
児に山佐電子歩数計を午前 9 時に装着させ，運動 あそびが終了した午前 11 時 30 分と, 午後 3 時の 2 回，歩数を記録した。

具体的には，登園時の体温を，全体の平均值と 


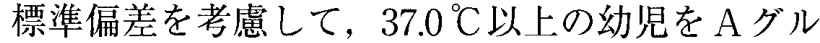

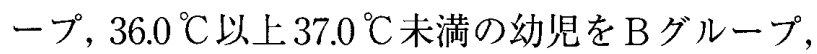
$36.0{ }^{\circ} \mathrm{C}$ 末満の幼児をCグループとして，3つのグ ループに区分した。

A グループに属する幼児は 181 名中 28 名 (15.5\%) となり，その午前 9 時の平均体温は

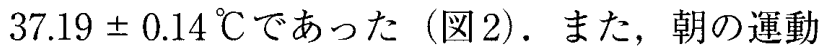
あそび実践後の午前 11 時 30 分においては，平均 歩数は 3209 歩を示しており（表6），体温は $36.89 \pm 0.34{ }^{\circ} \mathrm{C}$ となり, 午前 9 時に比較して有意 に低下した $(\mathrm{t}=4.32, \mathrm{p}<0.001)$. その後，午後 3 時には，体温 $36.92 \pm 0.40{ }^{\circ} \mathrm{C}$, 歩数 4699 歩とな った。

Bグループの 127 名 $(70.1 \%)$ については，午 前 9 時に $36.48 \pm 0.26{ }^{\circ} \mathrm{C}$, 運動後の午前 11 時 30 分 には歩数が 3014 歩となり, 体温は $36.62 \pm 0.46{ }^{\circ} \mathrm{C}$ と有意に高くなった $(\mathrm{t}=2.99, \mathrm{p}<0.01)$. その 後, 午後 3 時には, 平均体温は $36.63 \pm 0.40{ }^{\circ} \mathrm{C}$, 歩数は 4441 歩となった。

また，Cグループの幼览 26 名 $(14.4 \%)$ の平均 体温は，午前 9 時に $35.58 \pm 0.30{ }^{\circ} \mathrm{C}$ であり，午前 11 時 30 分には, 平均歩数 2817 歩で，体温は $36.27 \pm 0.42{ }^{\circ} \mathrm{C}$ と, 午前 9 時の体温に比し有意に 高くなった $(\mathrm{t}=6.82, \mathrm{p}<0.001)$. そして，午後 3 時には $36.47 \pm 0.51^{\circ} \mathrm{C}$ となり, 午前 11 時 30 分の 体温に比し, 高くなった. また, 歩数は3993歩 となった。

次に，それぞれのグループの園内生活時の体温 の日内レベルをみると, Aグループの幼巟では, 登園時の体温は, BとCのグループの体温に比し て有意に高くなった $(\mathrm{t}=13.99, \mathrm{t}=25.57, \mathrm{p}<$ 0.001）。また，午前 11 時 30 分においても，A グ ループの体温は，B拉よびCグループの体温に比 して有意に高く維持しており（ $\mathrm{t}=2.93, \mathrm{t}=5.98$, $\mathrm{p}<0.01-0.001)$ ，午後 3 時の体温も，B・Cグ ループに対して有意に高く $(\mathrm{t}=3.47, \mathrm{t}=3.62$, $\mathrm{p}<0.001)$ ，同様な様相を呈した。

$\mathrm{B}$ グループの登園時の体温と午前 11 時 30 分の 体温は，Aグループよりも有意に低く（ $\mathrm{t}=13.99$, $\mathrm{t}=2.93, \mathrm{p}<0.001), \mathrm{C}$ グループよりも有意に高 く維持された $(\mathrm{t}=3.58, \mathrm{p}<0.001)$. そして, 午

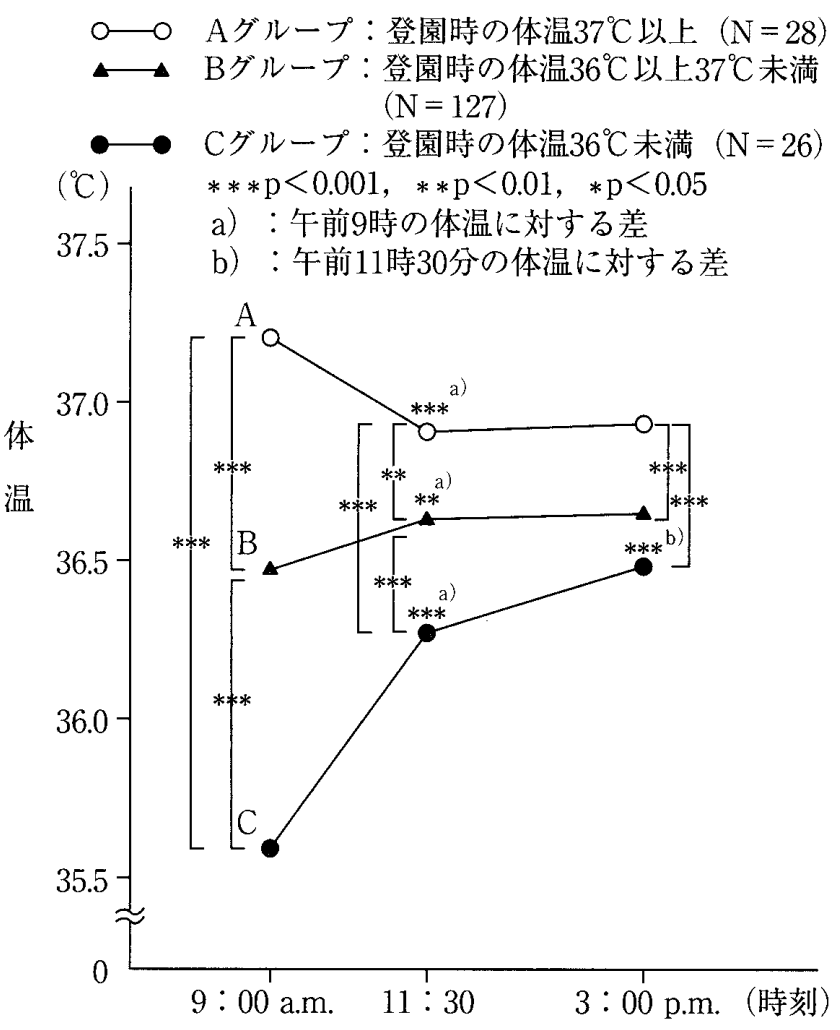

図2 登園時（午前 9 時）の体温別にみた 5 歳児の体温の 園内生活時変動

表 6 各グループの午前中にお ける平均歩数

\begin{tabular}{ll}
\hline $\mathrm{A}$ グループ & $3209 \pm 1386$ 歩 \\
$\mathrm{B}$ グループ & $3014 \pm 1410$ 歩 \\
$\mathrm{C}$ グループ & $2817 \pm 1266$ 歩 \\
\hline
\end{tabular}

後 3 時では，BグループとCグループの体温に有 意な差は認められなかった。

なお， 2 元配置の分散分析の結果では，「午前 9 時の体温区分」と「時間変化」の要因は，体温の 日内変動とは関わりがなかったことを付記してお $<$.

\section{2. 実践 2：「運動の継続実践」}

運動は継続的にさせることが重要と考え, 実践 1 の対象に対し，2 時間の運動あそびを，18日間 行ってもらった。ただし，運動あそび前後の調査 は，午前 9 時と午前 11 時に実施した。この 2 時間 の運動の継続によって，体温調節のうまくできな い子どもの割合の変化を調査・分析した. 


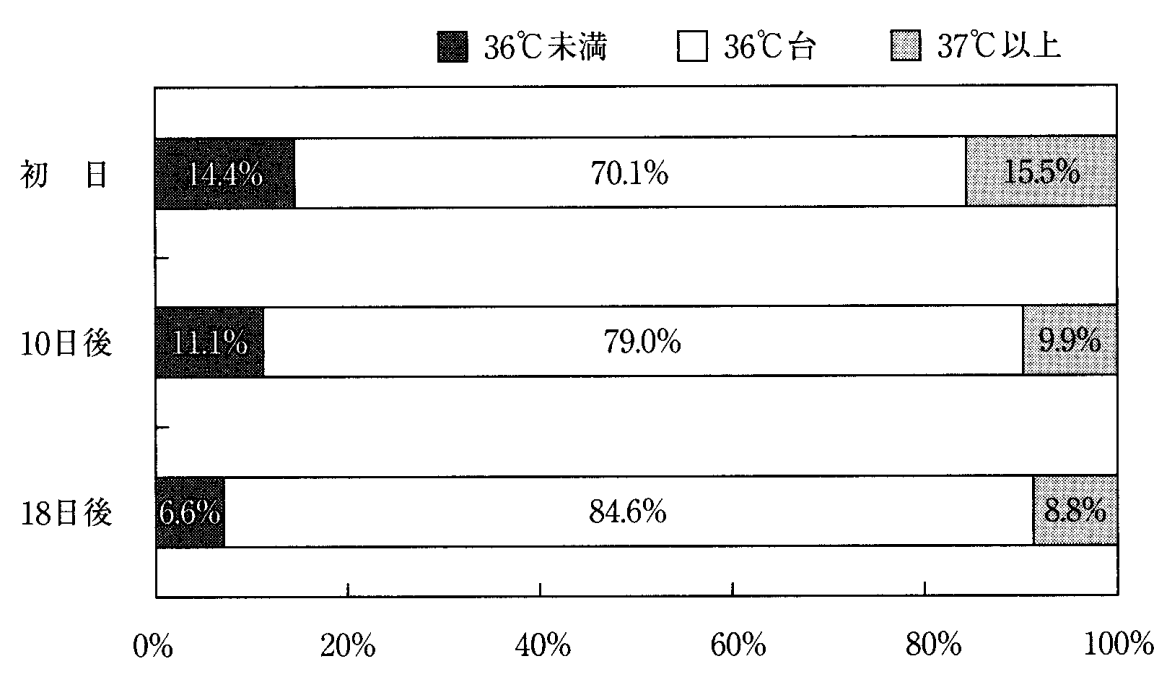

図3 5歳児 181 名に対する18日間の運動実践による体温区分割合の変化

つまり，体温異常の子どもを含む 181 人に，毎 日 2 時間の運動をさせる実験を行った。しかも， 1日のことだけでなく，運動実践は継続的にさせ ることが重要と考え, 全保護者の協力が得られた 18 日間実施した。この運動の継続によって，低 体温児は，初日 $14.4 \%$ あったのが，10日後に は11.1\%に，そして，18日後には6.6\%と減少し た（図3）。また，高体温児は，初日 $15.5 \%$ あ゙あ ったのが，10日後には9.9\%に，そして，18日後 には $8.8 \%$ とった。一方, $36{ }^{\circ} \mathrm{C}$ 台の幼児は $70.1 \%$ から $79.0 \%, 84.6 \%$ へと漸増した。つまり， 体温調節のうまくできない子どもたちが半減した のであった.

さらに，自律神経を鍛え，幼児がより快適な生 活を営むことができるようにするためには，運動 実践だけでなく，生活りズムを整える努力をする ことが必要と考え，あわせて早寝早起き，朝食の 摂取を呼びかけた。

\section{IV 幼児の体温と運動効果について}

体温の日内変動や年間変動については，一般成 人を対象に，研究がなされ，その成果が報告され ているが, 幼児の体温については，未だ詳細に解 明されていないのが実状である。ただし，これま での研究成果から, 乳幼児期には体温調節機能が 未発達のために，外部環境の影響を受けて，体温 は変動すること, また,一般に, 生後 3 日間くら
いは，比較的高温の時期が見られ，漸次下降して 100 日を過ぎると，およそ $37.0^{\circ} \mathrm{C}$ からそれ以下と なり，約 120 日位で安定すること（前橋，2001） がわかっている，そして，2歳頃より，生理的な 日内変動がみられてくる，個人差はあるが，3歳 頃になると，多くの子どもは体温調節がうまくな って（正木，2001），体温は生体リズムに従って， 1 日の内に $0.6-1.0{ }^{\circ} \mathrm{C}$ の変動を示すようになる (阿部，1979)。また，日常生活では，午前 2 時か ら 5 時の夜中 ・明け方に最も低く, 午後 3 時から 6 時の夕方に最高となる一定のサイクルが筑き上 げられる。このような日内変動は，ヒトが長年に わたって獲得した生体リズムの1つと考えられて いる.

さらに，中山ら（1982）は，これまで成人を対 象とした報告において，体温の同調化因子として 明暗, 湿度, 温度, 気圧, 音, その他, 外界から 生体に影響を及ぼす因子とともに，生活習慣も重 要な因子であると報告している。また，Tokura ら（1974）は, 光が同調化因子として作用すると している，つまり，体温の季節変動（概年リズム） は，生体の適応現象であり，同一環境下での熱産 生, 発汗反応, 皮膚血流等, 体温調節による機能 は季節によって変動するといわれている（矢住, 1974）中で, 本研究では, 高体温, 低体温ともに, 気温よりも日長時間の影響が強いことが明らかと なった。したがって，体温については，年間変動 が認められ，季節的な影響については，日長時間 
の長短が気温よりも影響されるという知見を得 た。

この体温調節機能を高めている背景には, 睡眠 と覚醒のリズム, 排便リズム, 身体活動量の増減, 握力の克進，LBM 量などが相互に関連しており， 種々の要因を考慮する必要があるが,すでに近年, 幼児の就寝時刻の遅延および睡眠時間の短縮が登 園時の高体温児の発現頻度と関連していることが 明らかにされており，環境的同調因子が物理的同 調因子以上により強く影響した例（毎日新聞， 2000b ; 前橋ほか, 2000 ; 岡崎ほか, 2000）が報 告されている.

本調查では, 登園した午前 9 時の体温の変動幅 は, $36.3^{\circ} \mathrm{C}-36.9^{\circ} \mathrm{C}$ 範囲にあり，佐々木 (1987) の「体温の概日リズムに対する最適余弦曲線のあ てはめ，およびその信頼区間」を参考にすると， それほど懸念することはないものと考えられる。 しかし，標準偏差を考慮すれば，登園時の体温を 園児の健康状態の指標として活用するためには， 体温の季節変動をも配慮する必要があろう。また， 前夜からの睡眠時間，起床から登園までの生活状 況が体温に影響するとすれば，この点にも注意し なければならない。

なお，運動との関わりをみるために， $36{ }^{\circ} \mathrm{C}$ 台 からはずれた低体温児と高体温児の出現頻度の多 かった 12 月の午前中に，保育園児に運動を実践 してもらった際，園内生活時における体温はどの ように変化するかを調査すると，子どもたちが運 動的なあそびを行うことによって，各グループの 登園時にみられていた体温の差が，平均 $1.61{ }^{\circ} \mathrm{C}$ か ら $0.45{ }^{\circ} \mathrm{C}$ へとさくなっていったことから，運動 あそびの実施が体温調節に一役を担っていると考 えられた。つまり，登園時の体温が $37.0^{\circ} \mathrm{C}$ より低

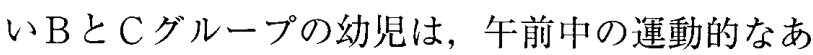
そびの後に，いわゆる筋肉活動を通して産熱し， 体温は上昇した。それに対し，登園時に $37.0^{\circ} \mathrm{C}$ 以

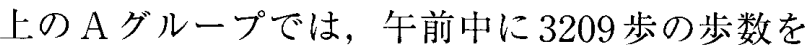
確保し，B・Cグループの幼児よりも，1人あた りの平均歩数が $200-400$ 歩程度多いにもかかわ らず，体温は低下した。

このことより, 登園時の体温が $37.0{ }^{\circ} \mathrm{C}$ 以上であ
った幼児の放熱機能は，登園後の身体活動により 活性化され，体熱放散への対応が速く，体温の低 下を導いたものと推測された。特に，この 28 名 の幼児の家庭での生活状況（環境）を調查すると， 共通して, 冷暖房が完備されて, 快適な室内の温 度環境で多くの時間を過ごしていることと，全員 が自家用車通園，そして，家庭において，毎日 2 時間以上のテレビ・ビデオ視聴が習慣化されてい た.そのため，戸外での温度変化に対する適応と， 運動時の産熱・放熱調節の機能低下を招ねいてい たと推察された。つまり，冷暖房が完備され，年 中過ごしやすく，温度差の影響の少ない状況下で 生活する近年の幼児の汗腺の機能が低下し，特に 冬季の暖房や厚着の場合には体温は上昇し（今村 ほか，1994），そのまま保育園児は車での登園と なり，本調查結果で示したように登園時体温は高 く維持され，身体の放熱が適切に行われない可能 性があるのかも知れない。

いずれにしても，体温や発汗の調節機能を高め るために，戸外での積極的な運動や運動あそびを 行わせることは，低体温の子どもの体温を上げる だけでなく， $37.0^{\circ} \mathrm{C}$ 以上の高めの子どもの体温を 低下させ，A，Cグループどちらの体温も $36.0-$ $37.0{ }^{\circ} \mathrm{C}$ 台の範囲に収めていくのである。つまり, 運動をさせることによって，体温調節が正常に機 能するのであろう。

なお，筆者は，これまで体温の高まりは，生体 の活性レベルの指標として捉え，登園時の体温を 高めることの必要性を強調してきたが，6月の生 活状況ならびに身体状況にもみられるように，午 前 9 時の体温が $37.0{ }^{\circ} \mathrm{C}$ 以上览の生活状況はすべて の項目において，36.0 ${ }^{\circ} \mathrm{C}$ 以上 $37.0{ }^{\circ} \mathrm{C}$ 末満のそれに 比較して低值であったことと，また，睡眠時間は， $37.0{ }^{\circ} \mathrm{C}$ 以上群では短く, 排便実施率も低值となり, 握力は 1 日を通して低く維持され，歩数は少なく なった。つまり，生活状況や身体状況は，体温や 握力值に反映し, 高体温児の発現が高まることは, 望ましいものではないことを示すものであった。 そして, 登園時には $36.0{ }^{\circ} \mathrm{C}$ 台の状態が望ましいこ とであり，体温の較差を少なくするためには，幼 児の生活リズムを整え，日々の生活に運動を取り 
入れ，体力の強化を図ることが大切であると考え る.

さて，体温異常の子どもを含む 181 人に，毎日 2 時間の運動を 18 日間行った結果, 体温調節のう まくできない子どもが半減したことより，自律神 経を鍜え，幼児がより快適な生活を営むことがで きるようにするためには，生活リズムを整える努 力をするだけでなく, 運動実践の継続が必要とい うことであった，言い換えれば，子どもにとって 運動あそびはそれくらい重要なのである.

\section{V 子育てや保育に寄与すべき事項の検討}

子どものからだの異変には，運動したり，遊ん だりするための環境や，家庭での生活習慣などが 密接に関わっている. たしかに, 夜型の生活, 少 子化, 母親の社会進出が進む中, 親が子どもの相 手になって十分に遊ばせ，早寝早起きにつき合っ ていく努力が必要である．現実問題としては，難 しいだろうが，今，安易に見過ごしてしまうと， 将来, 取り返しのつかないことが起こる.いや, もう，起き始めている，子どもの心と体は，見え ないところで想像以上に深く結びつき，生活状況 や身体状況の悪さを通して, 大人に危険信号を送 っている.

体温を調節する自律神経の異常は，心や感情と 深く関わっており，もし，心に問題があれば，そ れは体にも表れてくるであろうし，逆に体に問題 があると，いわゆる心の問題という部分にも表れ てくるはずである。つまり，心に変調をきざして いる子どもたちには，実は体に異変が起きている ということである. 幼児期から, 朝食や睡眠時間, 排便, 体温, 歩数などを細かくチェックしてみる と, 子どもたちの抱える問題の誘因や原因が手に とるようにわかる. 子どもの心の問題が，体温に も表れてくるからである.

さて, 近年の子どもたちの生活は夜型化して, 基本的には生活りズムが大きく乱れてきた。た， 便利で豊かな生活をして運動刺激が少なくなった ことで，自律神経，本来の働き方が悪くなってき た.つまり, 生活のリズムが悪いと, 生体のリズ
ムとの間に歪を生じ，反射的に行われていた体温 調節ができにくくなるのである，そこで，自律神 経を鍛え，幼児がより快適な生活を営むことがで きるように援助するためには，次の 5 点が大切で あると考えた。

（1）日中に運動や運動あそびを，戸外でしっか りさせて疲れさせ，夜に心地よい眠りにつけるよ うに配慮すること. 歩くこと, 徒歩通園を有効に 利用すること，1日の身体活動量（歩数）を増や すことが大切である．また，午前中の運動だけで なく，体温の高まった午後のダイナミックな運動 あそびの展開と充実がとくに必要である.

(2) 夕食前の扔やつや夜食は与えないこと。午 後 3 時頃の打やつは必要であるが, 夕食直前の扔 やつは，夕食が食べられなくなり，夜食摄取の誘 因となるため控えること. 午後の後半は, 体温が 最も高まる時で，いろいろなことが活発にできる 時間带である．子どもには，テレビを見ながらの おやつに代わって, 戸外での集団あそびを推薦し， 活動的に遊ぶようにさせることが大切である。ま た，夜食を食べると，快眠を得られず，翌朝は空 腹感が得られないため, 朝食を欠食する。そうす ると, 朝食分の必要摄取エネルギーの補充を夕食 前のおやつや夜食で補おうとする悪循環を生じる ので, 注意が必要である.

（3）親の社交のために, 夜間, 幼児を連れ回さ ないこと, 遅くても午後 9 時頃までには就寝させ, 少なくとも夜間は 10 時間以上の睡眠時間を確保 させることが，翌朝の疲労のレベルを低く維持す るために重要である。つまり, 生活に規則正しい リズムを持たせることである。

（4）朝は，朝食を十分に食べさせ，家で排便の できるゆとりの時間を子どもに保障すること，朝 食の前に体を動かす習慣をつくることが大切であ る.

仮に朝食はとったとしても，スナック菓子程度 では, 成長期の子どもが必要とする食事の質と量 としては不十分で, ウンチも出ない。また, 登園 中の車内や，園の駐車場での食事では，子どもの 情緒は安定しない。あわてて食べて園に駆け込む のでは，子どもはきまって朝のあそび中にウンチ 
をする，友だちとの社会性をはぐくむあそびの最 中に便意を生じ，トイレに駆け达まなければなら ない.これでは, 健康的なウンチは出ないし, 人 と関わる力も育たない.

便は食べものが体内で消化吸収された残りかす で，長い腸を通って出てくる，つまり，腸の中に 満ちるだけの食べものがなければならないのであ る. 朝食を欠食すると一日二食となり, 腸内の量 が満たされず，便秘しがちになる，便が一定の量 にならないと,排便のための反射を示さないため， 食事の内容は便の重さを作るものでもあることが 求められる. 特に菓子パンと牛乳といった簡単な ものであると，重さも量も不足して食物の残りか すができにくく，便秘しがちになってしまう。ま た，便にはほどよい柔らかさが必要である．特に 朝の水分補給が重要で，みそ汁やスープなどをし っかりとらせてもらいたい。卵や魚, 肉などのた んぱく質の多い主菜だけに偏ると, 便秘しがちに なるが，野菜や芋，海草でつくる副菜は排便を促 す。心地よい排便には，食事に主菜と副菜の両方 が整っていることが大切なのである.

排便の不調は十分な量の朝食と時間的なゆとり をつくることで，解決できそうである，そのため には早めに就寝し，十分な睡眠時間と質のよい睡 眠を確保することが欠かせない。食欲は朝起きて すぐにはわかない，早起きをして胃が空っぽのと ころへ食物を入れれば，その刺激を脳に伝えて大 腸のぜん動運動が始まり，便意をもよおす。また， 朝食を食べても出かけるまでに 30 分はないと， 排便には至らないことが多い，朝，排便をすませ ていないと，日中十分に筋力を発揮できず，快適 に活動できないこと（前橋, 2000）も分かってい る.子どもたちには，ぜひ朝食を食べさせた上で， 排便をすませ，ゆとりを持って登園させたいもの である。

（5）必要時以外は，冷暖房に頼らない努力をす ること.

今日の子どもは，とかく冷暖房の利いた室内の 快適環境での静的なあそびやテレビ・ビデオ視聴 をすることが多い。五感を鍛え，自律神経機能や 体温調節機能を高めるためにも, 戸外に出て, 仲
間といっしょに汗をかいて，脈拍が高まる運動あ そびを優先させることが極めて重要である．テレ ビゲームによって「バーチャル」に経験するより， 実際の体験や行動を友だちと共有し，戸外で自然 の空気に触れながら，本物の感動や感激を味わう ことこそが，子どもたちの豊かな感情や感覚機能 をも育て，強い耐性が身につくのである。

最後に，子どもたちの生活リズムの整調のため のポイントである「早寝早起き」のための方策を 考えてみたい。

まず，早寝ができるようにするためには，

(1)太陽の下で十分運動させ，心地よい疲れを得 るようにさせる。

午前中だけでなく，午後 3 時以降の運動あそび を充実すれば，夕方にはおなかがすいて夕食に専 念でき，午後 8 時ごろには眠くなる．反対に昼， 部屋の中でテレビを見たり，夕食前におやつを食 ベながらテレビゲームをすると，心地よい疲れが 得られず，なかなか眠れない。

(2)夕食と入浴を早めに済ませ，遅くまでテレビ を見せない.

テレビを見る時刻や寝る時刻を決め，寝る前に 飲食や過度な運動をさせないことが大切である。 睡眠の前に活発な運動をすると，大脳が活性化し て眠れなくなる，夜は，入浴で体を温め，リラッ クスさせるのが一番であろう。

(3)家族が寝る体制を作る。

協力して子どもが安心して眠れる環境を作ろ う．寝室にテレビの音や話し声が聞こえないよう にした上で，静かで優しい音楽を流すのも良い方 法である。

(4)翌朝の通園が楽しみという雲囲気をつくる. もちろん，園での友だちや先生との再会や，楽 しい園活動への興味づくりをすることは，有効で ある。

次に，早起きのためには，

(1)カーテンを薄めにし，朝日が射し込むように する。

朝になったらカーテンを開け，外の新鮮な空気 と光を部屋に入れる。また，ベッドの位置を空の 近くに移し，戸外の小鳥の鳴き声や生活音などが 
自然な形で入りやすくする.

(2)寝ついたらエアコンを切り, 例えば，冬は寒 気で自然に目覚めるようにする。

(3)楽しく起きることのできる工夫をする.

おいしい朝食を作り，起きる時間に子どもの好 きな音楽をかけたりする，子どもの好きな目覚ま し時計を使うのも良い方法であろう．時には，朝 食のにおいを流してみてはどうだろうか。

(4)親が早く起きて見本を示す.

要は実現可能な目標を設定することが大切であ る. 決してたくさんではなく，一つずつが望まし w.

以上，今の幼児には，運動の実践と生活リズム の整調が絶対に必要で, 特に運動については, 大 人が意識的に運動の機会を設けていく努力が求め られている，要は，戸外で元気に遊んでもらえば よいのである，飛んだり，跳ねたり，転がったり， 走り回ったりすることで, 筋肉は無意識のうちに バランスよく鍛えられ，体温も上がる。その結果, ホルモンの分泌も良くなり, 自然に活動型の正常 なリズムに戻っていく.ただ，今の子どもたちは， 集団でのあそびを苦手としている傾向にあるの で，ここにひと工夫が必要である，このため，保 育者が子どもたちといっしょになって遊び，昔の ガキ大将のように遊び方を教え，子ども自身が体 を動かすことが楽しくなるように配慮する「保育 者の努力と工夫，援助」が必要であろう.

\section{VI おわりに}

近年，低体温の子どもに加えて，高体温児と午 前中に体温が $1{ }^{\circ} \mathrm{C}$ 以上変動する子どもが増加して きたことより, 問題解決のカギは, 生活習慣と運 動量にあると考え，体温調節がうまくできない子 どもの生活リズムを立て直す努力をするととも に，子どもたちを戸外で思いきり遊ばせる実践を 行ってきた，その結果，

（1）子どもたちに運動を取り入れることによっ て，登園時にみられていた体温の個人差が小さく なり，体温調節を司る自律神経が正常に機能する ことを確認した。また，体温異常の子どもを含む
181 人に，毎日 2 時間の運動を 18 日間継続して行 ってもらった結果, 体温調節のうまくできない子 どもが半減した。したがって, 体熱の産生と放散 の調整のバランスのとれた身体の機能を高めるた めに，生活のリズムを整えるとともに，生活の中 に戸外での運動実践を取り入れた体温調節のトレ ーニングが, 幼児期から求められるといえる.

（2）早寝早起きの睡眠のリズムを整え，朝食を 食べて排便をし，歩いて登園させることで，子ど もたちの体温は登園時に高まる。この体温の高ま りが，心身のウォーミングアップとなって，登園 してからの活動効辩は上がり，エネルギー発揮が 良くなる，特に，午前中の運動あそびや諸活動は もちろんであるが，昼寝を終えて元気になった午 後 3 時以降の運動あそびの充実を図れば, 夕食前 のおやつや遅寝の問題は解決に向かうであろう. 遊んだ後はお腹がすき, 夕食に専念する。そして, 夜には心地よい疲れが生じ，午後8時頃にはクラ リクラリと睡魔を生じる. いつもテレビを見なが ら保育園でお迎えを待ったり, 家でおやつを食べ ながらテレビゲームをしたりする子どもが激増し てきており，これを改善することが, 現代の子ど もの健康法かも知れない.

保育園や幼稚園では，園児の生活リズムを立て 直すために，「早く寝て睡眠時間を 10 時間以上と る」，「早く起きてしっかり朝食をとる」ことを， 保護者へ啓発するとともに，戸外で活発に運動す る機会を, 子どもたちに十分与えることが大切で ある。そうすると，大脳や自律神経などの身体機 能の活性化が図れるだけでなく，それらの変化に 伴って,少しずつ子どもたちの集中力や意欲にも， 良き方向への変化がみられるようになるであろ う.

本稿の内容は, 部分的ではあるが，（1）朝日新 聞社 AERA「子どもが壊れる (2000年 4 月 17 日)」, （2）北海道新聞「教育：温度差少ない環境 抵抗 力低下が心配 (2000 年 5 月 15 日)」, (3) 毎日新 聞「医療リポート：夜型で調節機能変調：握力な ど著しい低下（2000年 7 月 1 日)」，（4）フジテレ ビ・スーパーニュース「子どもの体が危ない 
(2000年7月 14 日)」，（5）NHK クローズアップ 現代「子どもの体に異変（2000年8月1日）」，（6） 山陽新聞「幼児の高体温: 生活変え調節機能回復 を（2000年 8 月 23 日）」，（7）テレビせとうちナ イス 5 「幼児の高体温（2000年10月 2 日）」，(8) 東京テレビニュースアイ「子どもの心と体に異変 （2001年2月 13 日）」，（9）NHK教育フォーカス 「シリーズ 生きる力って何ですか？ 第 3 回力 ラダの危機はココロの危機（2002年4月 18日）」, （10）NHKきびきびワイド「子どもたちの体温異 常（2002年6月 11 日)」で採用・報道された。

\section{文献}

阿部和正（1979）看護生理学.メヂカルフレンド 社：東京, pp. 7-10.

今村榮一 - 巷野悟郎（1944）小児保健. 診断と治療 社：東京, pp. 41-44.

石井浩子 - 渋谷由美子 - 高橋ひとみ・前橋 明 - 中 永征太郎（1993）幼览期の体力・身体活動量と疲 労症状の訴元。幼少児健康教育研究，3（2）：2834.

石井浩子 - 渋谷由美子 - 前橋 明 - 中永征太郎

（1996）幼児の園内生活時に扔ける疲労スコアの週 内変動. 運動・健康教育研究, 5 (2)：7-11.

石井浩子 - 渋谷由美子 - 有木信子 - 前橋 明 - 岡崎

節子・中永征太郎 (2000) 保育園览の園内生活時 の歩数と生活状況 - 体温 - 握力との関連性. 幼少 児健康教育研究，9（1）：15-20.

甲賀正聰（1988）子どもの心と体の問題一低体温一.

教育と医学, 36 (1) : 2-75.

前橋 明 - 石飛小百合 - 渋谷由美子 - 石井浩子 - 高 皇多美子 - 中永征太郎（1993a）幼览期の疲労訴元 スコアの変動. 幼少児健康教育研究, 3（2）：1922.

前橋 明 - 石井浩子 - 中永征太郎 (1993b) 幼览にお ける登園時の痩労症状に及ぼす睡眠時間の影響. 倉敷市立短期大学研究紀要, $23: 29-33$.

前橋明 - 石井浩子 - 渋谷由美子 - 中永征太郎

（1994）保育園児における疲労の訴えスコアの変動 に及ぼす生活条件. 小児保健研究，53：709-715. 前橋 明 - 石井浩子 - 中永征太郎 (1997) 幼稚園児 ならびに保育園児の園内生活時における疲労スコ
アの変動. 小览保健研究, 56：569-574.

前橋 明 - 岡崎節子 - 有木信子 - 石井浩子 - 渋谷由 美子・中永征太郎（2000）保育園児の生活習慣 · 体温 - 筋力相互の関連性. 倉敷市立短期大学研究 紀要, $33: 41-48$.

前橋 明（2000）子どもの生活リズムの乱れと運動

不足の実態. 保健室, 87：11-21.

前橋 明 (2001) 健康. 明研図書：岡山, pp. 221222.

毎日新聞（2000a）医療リポート「増えている疲れた 子供，夜更かしが翌日に影響」. 2000 年 2 月 26 日. 毎日新聞 (2000b) 医療リポート「体力, 活動, 排便 に影響, 睡眠不足の夜型幼児増加」. 2000 年 2 月 19 日.

毎日新聞（2001）医療りポート「体温調節できない 子どもたち, 運動不足, 自律神経の機能低下」. 2001 年 3 月 10 日.

正木健雄（2001）ヒトになる，人間になる. 創教出 版 : 大阪.

中山明雄・丹羽建市（1982）体温リズムの調節機構.

蛋白質核酸酵素, $27: 308$.

岡崎節子（1998）体温のしくみと体温測定. 幼少児 健康教育研究, 7 (1)：88-95.

岡崎節子 - 前橋 明 - 渋谷由美子 - 石井浩子 - 中永 征太郎 (2000）幼児の朝の排便と睡眠時間 - 体 温 - 握力との関連性. 倉敷市立短期大学研究紀要, $33: 49-58$.

山陽新聞Ledya（2001）：育児と教育のコーナー 「子どもの生活リズムを大切に」. 2001 年 3 月 8 日. 佐々木隆（1987）体温の概日リズム。杉 晴夫編 人体機能生理学. 南江堂：東京, p. 633 .

淽谷由美子 - 石井浩子 - 前橋 明 - 中永征太郎 （1996）幼児の園内生活時における疲労スコアの日 内変動. 運動 - 健康教育研究, 5 (2) : 1-6.

Tokura, H. (1974) Comparison of circadian oral temperature rhythms between blind and normal subjects. J. Physiol. Soc., 36: 255-256.

矢住孝昭（1974）連続体温計による体温サーカデイ アンリズムに関する研究。聖マリアンナ医科大学 雑誌, $13 ： 256-632$.

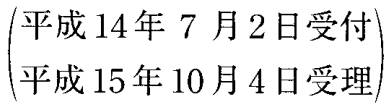

